\title{
Searching Kuznets Environmental Curve in Selected Islamic Country: A GMM Approach
}

\author{
Ahmad Assadzadeh, Abdolreza Ghorban-Sabbagh, Alireza Jalili-Marand, and Akram Akbari
}

\begin{abstract}
This article investigates the existence of Environmental Kuznets Curve, EKC relationship between countries' environmental performance and per capita income for sixteen Islamic countries during 1990-2007. In this regard, at first the environmental efficiency and Malmquist environmental productivity is measured for each country. Then the relationship between countries' environmental performance and per capita income has been investigated by a dynamic model. The result shows that there is an inverted-U pattern between income and environmental degradation in th studied countries.
\end{abstract}

Index Terms-Kuznets curve, Malmquist productivity, environmental efficiency, technical efficiency changes

\section{INTRODUCTION}

It has been a tough trade-off decision between economic growth and environmental protection. On the one hand, environmental activists believe that to increase economic growth it is necessary to raise level of energy. Hence, higher energy consumption causes higher population and environmental degradation, therefore the rate of economic growth should be decline; on the other hand, some economists in endogenous growth theory comment that economic growth can be lead to enhancement of environmental quality and reduction of population.

This trade-off has been discussed appropriately through environmental Kuznets curve (EKC). For the first time, [1] investigate the relation between income inequality and economic growth. By the empirical result, he postulated the inverted-U pattern between income inequality and economic growth. After Kuznets' distinguished work, economist proceeded to search relationship between income change and environmental quality; they achieve same pattern between income change and environmental quality. Due to this

similarity, pattern of the environmental pattern has been called an "environmental Kuznets curve". According to EKS, economic growth does not necessarily cause environmental degradation.

The logic of EKC relation is intuitively appealing. In the first stage of industrialization, pollution grows rapidly because people are more interested in jobs and income than clean air and water due to low level of per capita income and high rate of unemployment. The rapid growth leads greater

Manuscript received September 15, 2013; revised November 8, 2013.

Ahmad Assadzadeh and Alireza Jalili-Marand are with the Faculty of Economics, University of Tabriz, Tabriz, Iran (e-mail: Assadzadeh@gmail.com, alireza.jalili.m@gmail.com).

Akram Akbari with the Economics, Tabriz Business Training Center, Tabriz, Iran (e-mail: akramakbari98@yahoo.com). use of natural resources and more population. In later stage of industrialization, by increasing income, people value the environment more, regulatory institutions become more effective and pollution level declines. Thus, EKC hypothesis posits a well-defined relationship between level of economic activity and environmental pressure [2].

Since the mid-90's, most of studies consider only income and environmental degradation; such that GDP as a proxy of income and one of pollution as a proxy of environmental degradation. According to result of some studies during this time, we can conclude that in long-run by the income raising, at the first stage environmental degradation increases; but at second stage the level of environmental degradation will be declined. In other words, EKS hypothesis has been confirmed.

[3] Investigate the effects of economic growth and trade liberalization on environmental degradation; he obtained an inverted U-shaped relationship between pollution and income. [4] Explores the role of the income elasticity of demand for environmental, showing that preferences consistent with a positive income elasticity of demand for environmental quality are neither necessary nor sufficient for the EKC. [5] conclude that economic growth is not a panacea for environmental quality; what matters is the content of growth. In the scope of the theory of productive efficiency [6] takes three categories of firm's factor into account, i.e. inputs, desirable production outputs and pollutants in the form of 'undesirable' outputs to measure environmental performance of firms.

[7] Using cross-country city level data on environmental quality, find support for the EKC hypothesis with peaks at a relatively early stage of development. [8] perform an empirical analysis of international variations in seven indicators of air and water quality finding that literacy, political rights, and civil liberties have particularly strong effects on environmental quality in low-income countries.[9] find that a more capital intensive production technique (a higher per capita income level) would cause less pollution.

[10] Establish the link between environmental efficiency and per capita income using the Nadaraya-Watson kernel estimator and determine a cubic functional form for the relationship between environmental efficiency and GDP per capita without an a priori assumption. [11] Introduce the directional output distance function to credit reduction of beds as well as expansion of goods. The empirical results indicate that it might be more appropriate to use the Malmquist-Luenberger productivity index in the presence of bad outputs [12]-[15] also investigate the existence of EKC using different econometric methods and find evidences for this hypothesis. 
In contrast with common studies, this paper use productivity index as proxy for measurement of environment quality instead of pollutions. The paper is organized as follows: the following section presents theoretical background of EKS. The third section is allocated to the derivation of environmental efficiency and productivity indexes. The forth section presents the result of estimation of relation between income and environmental efficiency and last section is conclusion.

\section{THEORETICAL BACKGROUND OF EKS}

To present analytic description about EKS hypothesis, [16] introduce a simple analytics of the environmental Kuznets curve. This model begins with the simplifying assumption of an economy with only one person which has no externalities. The single agent gets utility only form two things: consumption of one private goods, named $\mathrm{C}$, and from a bad one which is pollution and denoted by P. Utility function of this agent is then:

$$
U=U(C, P)=C-P
$$

where $U_{C}>0$ and $U_{P}<0$, and $U$ is quasiconcave in $C$ and $-P$. Suppose further pollution is a positive function of consumption and a negative function of environmental effort:

$$
P=P(C, E)
$$

By the assumption of simple Cobb-Douglas about utility function, agent will maximize its utility with respect to income (endowment) constraint namely $C+E=M$ :

$$
\begin{array}{ll}
\max & U=C^{\alpha} E^{\beta} \\
\text { s.t } & M=C+E
\end{array}
$$

Optimal amount of $C$ and $E$ which maximize utility is obtained by solving (3). Whit substituting optimal $C$ and $E$ in utility function, we can derive optimal pollution:

$$
P^{*}(M)=\frac{\alpha}{\alpha+\beta} M-\left(\frac{\alpha}{\alpha+\beta}\right)^{\alpha}\left(\frac{\beta}{\alpha+\beta}\right)^{\beta} M^{\alpha+\beta}
$$

Eq. (4) represents the relation between income and pollution. The functional form of this relation directly depends on the parameters of Cobb-Douglas function: $\alpha$ and $\beta$. The derivative of Eq. (4) shows this dependence very well:

$$
\frac{\partial P^{*}}{\partial M}=\frac{\alpha}{\alpha+\beta}-(\alpha+\beta)\left(\frac{\alpha}{\alpha+\beta}\right)^{\alpha}\left(\frac{\beta}{\alpha+\beta}\right)^{\beta} M^{\alpha+\beta-1}
$$

\section{A. Productivity and Efficiency Measurement}

This paper investigates the relation between productivity as a proxy of growth and pollution. To calculate the each country's productivity it is necessary to evaluate environmental efficiency, because productivity arises both from changes in efficiency and technological changes. For measurement of efficiency this paper adopts a variation of the traditional DEA approach introduced by [17] which is called CCR models on the basis of Farrell's work in 1957. Several studies have used DEA analysis in order to measure efficiencies over time [18]-[25] developed CCR models to be consonant with variable returns to scale models and with multiple input and multiple output situations.

To construct efficiency index, we suppose whole of a country as a firm which uses inputs to produce outputs. Two inputs employment rate and the ratio of total investment to GDP and two outputs GDP and $\mathrm{CO}_{2}$ are considered as inputs and outputs of each country. In this respect firm (country) produce two outputs: bad and good outputs (growth and pollution). Using pointed schematic models, we first calculate the efficiency. The amount of emission of $\mathrm{CO}_{2}$ is one of outputs; therefore we can consider this efficiency as environmental efficiency.

Additional, to measurement of productivity we use Malmquist productivity index. For the first time, [26] used DEA to measure Malmquist productivity index. The advantage of MI is its ability to decompose the productivity. Changes in productivity are due to four sources:

\section{$\mathrm{MI}=\mathrm{TFP}=\mathrm{PTE} \times \mathrm{TECH} \times \mathrm{SE} \times \mathrm{TE}$}

where

PTE is total factor productivity change, PTE is pure technical (managerial) efficiency change, TECH is technological change, SE is scale efficiency change and TE stands for technical efficiency change.

\section{B. Data}

The sample is consisting of sixteen Islamic countries namely: Albania, Aljazeera, Bahrain, Bangladesh, Egypt, Indonesia, Iran, Jordan, Lebanon, Libya, Malaysia, Morocco, Oman, Pakistan, Tunisia and Turkey for the time period 1990-2007. Four variables are selected to calculate efficiency and productivity of each country: employment rate, the ratio of total investment to GDP, GDP and emission of $\mathrm{CO}_{2}$.

\section{Productivity and Efficiency Measurement Result}

Table I shows the average efficiency of each country. Three type of efficiency reported in Table I. Second column is technical efficiency; third column provides managerial efficiency and fourth one is about scale efficiency. Also the type of scale of production function is determined in last column. According to Table I only Bahrain and Bangladesh fully use its capacity. The efficiency of both countries is one for all three types. Albania and Libya respectively have 0.175 and 0.22 efficiency which are lowest technical efficiency among sample.

Average value of Efficiency of all countries within 1990-2007 is 0.499 . It means that only 49 percent of output has been achieved with the given amount of inputs on average. The returns to scale is increasing for ten countries; Bahrain, Bangladesh, Indonesia, Libya and Oman have constant returns to scale and only Malaysia and Turkey have decreasing retunes to scale. Also average retunes to scale is increasing.

We use result of Table I to evaluate the Malmquist productivity index. Table II shows Malmquist productivity with its component for sixteen countries of sample. Environmental productivity of Lebanon is 1.088 which is highest one. Bangladesh's productivity is 0.937 which is 
lowest environmental productivity due to low amount of changes in technological efficiency. Average productivity is 1.019 indicates that countries generally has improved productivity.

TABLE I: EFFICIENCY (AVERAGE VALUES OBTAINED BY DEA)

\begin{tabular}{|c|c|c|c|c|}
\hline Country & $\begin{array}{l}\text { Technical } \\
\text { efficiency }\end{array}$ & $\begin{array}{l}\text { Managerial } \\
\text { efficiency }\end{array}$ & $\begin{array}{l}\text { Scale } \\
\text { efficiency }\end{array}$ & $\begin{array}{l}\text { Type of } \\
\text { scale }\end{array}$ \\
\hline Albania & 0.175 & 0.218 & 0.803 & Increasing \\
\hline Aljazeera & 0.5 & 0.887 & 0.563 & Increasing \\
\hline Bahrain & 1 & 1 & 1 & Constant \\
\hline Bangladesh & 1 & 1 & 1 & Constant \\
\hline Egypt & 0.29 & 1 & 0.29 & Increasing \\
\hline Indonesia & 0.248 & 0.248 & 0.999 & Constant \\
\hline Iran & 0.361 & 0.387 & 0.932 & Increasing \\
\hline Jordan & 0.361 & 1 & 0.319 & Increasing \\
\hline Lebanon & 0.319 & 0.315 & 0.697 & Increasing \\
\hline Libya & 0.22 & 1 & 1 & Constant \\
\hline Malaysia & 1 & 0.337 & 0.959 & Decreasing \\
\hline Morocco & 0.323 & 0.592 & 0.634 & Increasing \\
\hline Oman & 0.375 & 1 & 1 & Constant \\
\hline Pakistan & 1 & 0.653 & 0.569 & Increasing \\
\hline Tunisia & 0.372 & 0.764 & 0.518 & Increasing \\
\hline Turkey & 0.395 & 0.395 & 0.984 & Decreasing \\
\hline Average & 0.499 & 0.676 & 0.767 & Increasing \\
\hline
\end{tabular}

TABLE II: AvERAge MALMQUIST PRODUCTIVITY AND CHANGES IN EFFICIENCIES

\begin{tabular}{|c|c|c|c|c|c|}
\hline \multirow[b]{2}{*}{ Country } & \multicolumn{3}{|c|}{ Technical Managerial Scale } & \multicolumn{2}{|c|}{ Technological Malmquist } \\
\hline & $\begin{array}{l}\text { efficiency } \\
\text { changes }\end{array}$ & $\begin{array}{l}\text { efficiency } \\
\text { changes }\end{array}$ & $\begin{array}{l}\text { efficiency } \\
\text { changes }\end{array}$ & $\begin{array}{l}\text { efficiency } \\
\text { changes }\end{array}$ & $\begin{array}{l}\text { environmental } \\
\text { productivity }\end{array}$ \\
\hline Albania & 1.061 & 1.073 & 0.989 & 0.996 & 1.057 \\
\hline Aljazeera & 0.969 & 0.951 & 1.019 & 1.031 & 0.999 \\
\hline Bahrain & 1 & 1 & 1 & 1.056 & 1.056 \\
\hline Bangladesh & & 1 & 1 & 0.937 & 0.973 \\
\hline Egypt & 0.998 & 0.992 & 1 & 0.991 & 0.989 \\
\hline Indonesia & 1.011 & 1.024 & 0.987 & 0.981 & 0.992 \\
\hline Iran & 0.982 & 0.995 & 0.987 & 1.037 & 1.019 \\
\hline Jordan & 1.004 & 1 & 1.004 & 1.026 & 1.030 \\
\hline Lebanon & 1.055 & 1.07 & 0.986 & 1.031 & 1.088 \\
\hline Libya & 0.983 & 1 & 0.983 & 1.041 & 1.023 \\
\hline Malaysia & 1.006 & 1.005 & 1.001 & 1.044 & 1.050 \\
\hline Morocco & 1.004 & 1.003 & 1.001 & 0.997 & 1.001 \\
\hline Oman & 0.994 & 1 & 0.994 & 1.018 & 1.012 \\
\hline Pakistan & 1.007 & 0.998 & 1.009 & 0.973 & 0.980 \\
\hline Tunisia & 1.002 & 1.016 & 0.986 & 1.019 & 1.021 \\
\hline Turkey & 1.025 & 1.052 & 0.974 & 1.04 & 1.066 \\
\hline Average & 1.006 & 1.011 & 0.995 & 1.013 & 1.019 \\
\hline
\end{tabular}

\section{SPECIFICATION OF Model AND Result OF Estimation}

To examine the existing of EKS, we specify following model:

$$
y_{i, t}=\gamma y_{i, t-1}+\sum_{j=1}^{r} \beta_{j} x_{i, t}^{j}+\eta_{t}+\mu_{i}+v_{i, t}
$$

where $y_{i, t}$ denotes environmental productivity (Malmquist environmental productivity). $\beta_{j} x_{i, t}^{j}$ denotes vector of explanatory variables. $\eta_{t}$ is time specific intercepts and $\mu_{i}$ is country's specific effect. Explanatory variables are comprised of: GDP per capita (GDPC), square of GDP per capita $\left(\mathrm{GDPC}^{2}\right)$ and urban population $(\mathrm{Ub})$. Then Eq. (6) is written as follows:

$$
y_{i, t}=\gamma y_{i, t-1}+\beta_{1} G D P_{i, t}+\beta_{2} G D P_{i, t}^{2}+\beta_{3} U b_{i, t}+\eta_{t}+\mu_{i}+v_{i, t}(7)
$$

Eq. (7) is dynamic because the lag of dependent variable involves as independent variable at right-hand side of equation. Therefore, it is inappropriate to use classic panel data estimator such as fixed effect and random effect. To estimate Eq. (7) we use Arellano and Bond's GMM estimator. Table III shows estimation result for Eq. (7).

\begin{tabular}{|c|c|c|c|}
\hline Model & Fixed Effects & $\begin{array}{l}\text { Random } \\
\text { Effects }\end{array}$ & GMM \\
\hline Constant & $\begin{array}{l}0.866 \\
{[0.000]}\end{array}$ & $\begin{array}{l}0.866 \\
{[0.000]}\end{array}$ & $\begin{array}{l}0.209471 \\
{[0.08]}\end{array}$ \\
\hline GDPC & $\begin{array}{l}-0.008 \\
{[0.006]}\end{array}$ & $\begin{array}{l}-0.008 \\
{[0.040]}\end{array}$ & $\begin{array}{l}-0.0008 \\
{[0.1]}\end{array}$ \\
\hline $\mathrm{GDPC}^{2}$ & $\begin{array}{l}0.0000026 \\
{[0.028]}\end{array}$ & $\begin{array}{l}0.0000026 \\
{[0.136]}\end{array}$ & $\begin{array}{l}0.000000046 \\
{[0.02]}\end{array}$ \\
\hline $\begin{array}{l}\text { Urban } \\
\text { Population }\end{array}$ & $\begin{array}{l}0.00749831 \\
{[0.002]}\end{array}$ & $\begin{array}{l}0.00749831 \\
{[0.018]}\end{array}$ & $\begin{array}{l}-0.321280 \\
{[0.09]}\end{array}$ \\
\hline$y_{\mathrm{t}-1}$ & & & $\begin{array}{l}0.444898 \\
{[0.08]}\end{array}$ \\
\hline $\begin{array}{l}\text { Test for } 2 \text { nd } \\
\text { order serial } \\
\text { correlation }\end{array}$ & 0.207 & 0.067 & 0.374 \\
\hline Sargan test & & & 0.997 \\
\hline
\end{tabular}

TABLE III: ESTIMATION RESULT

Second column in Table III provides result of performing fixed effect estimator. The lag of environmental productivity has been removed from model because FE is appropriate only for non-dynamic equation. All coefficients are significant and the sign of coefficient are matching expectation. The negative sign of GDP along with the positive sign of Square of GDP conform EKS hypothesis.

The third column shows the result of random effect estimator. The results don't have substantial difference with FE estimator and EKS hypothesis is also conformed. And finally last column shows the result of GMM estimator for Eq. (7). As noted, one of consistent estimator to estimate moderate dynamic panel model is Arellano and Bond's estimator which is based on GMM method. According to result, coefficient of square of GDP per capita which is significant at the 5 percent level has negative value. Thus, Kuznets type relationship between countries environmental efficiency and income per capita does not reject in selected countries.

Also all variable are significant at 10 percent and especially the lag of environmental efficiency. The The results from Sargan test of overidentifying restrictions which examines the validity of the moment conditions used in the GMM estimation procedure, no longer reject the null hypothesis that the overidentifying restrictions are valid. Urban population is negative in GMM estimation unlike with FE and RE which indicates negative effect of high population on environmental improvement.

\section{CONCLUSION}

This article investigates the existence of EKC relationship between countries' environmental performance and per-capita income for sixteen Islamic countries during 1990-2007. In this regard, at first the environmental efficiency and Malmquist environmental productivity is measured for each country. Then the relationship between countries' environmental performance and per-capita income 
has been investigated by a dynamic model. The result shows that there is an inverted- $U$ pattern between income and environmental degradation.

\section{REFERENCES}

[1] S. Kuznets, "Economic Growth and Income Inequality," The American Economic Review, vol. 45, no. 1, pp. 1-28, 1955.

[2] S. Dasgupta et al., "Confronting the environmental Kuznets curve," The Journal of Economic Perspectives, vol. 16, no. 1, pp. 147-168, 2002.

[3] R. Lopez, "The environment as a factor of production: The effects of economic growth and trade liberalization," Journal of Environmental Economics and Management, vol. 27, no. 2, pp. 163-184, 1994.

[4] K. E. McConnell, "Income and the demand for environmental quality," Environment and Development Economics, vol. 2, no. 4, pp. 383-399, 1997.

[5] K. Arrow et al., "Economic growth, carrying capacity, and the environment," Science(Washington), vol. 268, no. 5210, pp. 520-521, 1995.

[6] D. Tyteca, "On the measurement of the environmental performance of firms - A literature review and a productive efficiency perspective," Journal of Environmental Management, vol. 46, no. 3, pp. 281-308, 1996.

[7] G. M. Grossman and A. B. Krueger, "Economic growth and the environment," The Quarterly Journal of Economics, vol. 110, no. 2, pp. 353-377, 1995.

[8] M. Torras and J. K. Boyce, "Income, inequality, and pollution: A reassessment of the environmental Kuznets curve," Ecological Economics, vol. 25, no. 2, pp. 147-160, 1998.

[9] S. Dinda, D. Coondoo, and M. Pal, "Air quality and economic growth: An empirical study," Ecological Economics, vol. 34, no. 3, pp. 409-423, 2000.

[10] F. Taskin and O. Zaim, "Searching for a Kuznets curve in environmental efficiency using kernel estimation," Economics Letters, vol. 68, no. 2, pp. 217-223, 2000.

[11] Y. H. Chung, R. Färe, and S. Grosskopf, "Productivity and undesirable outputs: A directional distance function approach," Journal of Environmental Management, vol. 51, no. 3, pp. 229-240, 1997.

[12] A. K. Jorgenson, "Unequal Ecological exchange and environmental degradation: A theoretical proposition and cross- national study of deforestation, 1990-2000," Rural Sociology, vol. 71, no. 4, pp. 685-712, 2006

[13] S. Managi and P. R. Jena, "Environmental productivity and Kuznets curve in India," Ecological Economics, vol. 65, no. 2, pp. 432-440, 2008.

[14] D. Ciriaci and D. Palma, "The role of knowledge-based supply specialisation for competitiveness: A spatial econometric approach," Papers in Regional Science, vol. 87, no. 3, pp. 453-475, 2008.

[15] J. Fosten, B. Morley, and T. Taylor, "Dynamic misspecification in the environmental Kuznets curve: Evidence from $\mathrm{CO}_{2}$ and $\mathrm{SO}_{2}$ emissions in the United Kingdom," Ecological Economics, vol. 76, pp. 25-33, 2012.

[16] J. Andreoni and A. Levinson, "The simple analytics of the environmental Kuznets curve," Journal of Public Economics, vol. 80 no. 2, pp. 269-286, 2001.
[17] A. Charnes, W. W. Cooper, and E. Rhodes, "Measuring the efficiency of decision making units," European Journal of Operational Research, vol. 2, no. 6, pp. 429-444, 1978.

[18] A. Charnes et al., "Foundations of data envelopment analysis for Pareto-Koopmans efficient empirical production functions," Journal of Econometrics, vol. 30, no. 1, pp. 91-107, 1985.

[19] H. Tulkens and P. Vanden Eeckaut, "Non-parametric efficiency, progress and regress measures for panel data: Methodological aspects,' European Journal of Operational Research, vol. 80, no. 3, pp. 474-499, 1995.

[20] T. E. Hartman and J. E. Storbeck, "Input congestion in loan operations," International Journal of Production Economics, vol. 46, pp. 413-421, 1996.

[21] R. Webb, "Levels of efficiency in UK retail banks: A DEA window analysis," Int. J. of the Economics of Business, vol. 10, no. 3, pp 305-322, 2003

[22] M. Asmild, et al., "Combining DEA window analysis with the Malmquist index approach in a study of the Canadian banking industry," Journal of Productivity Analysis, vol. 21, no. 1, pp. 67-89, 2004.

[23] W. W. Cooper, L. M. Seiford, and K. Tone, "Data envelopment analysis: A comprehensive text with models, applications, references and DEA-solver software," Springer Science and Business Media, 2007.

[24] G. Halkos and N. Tzeremes, "Trade efficiency and economic development: Evidence from a cross country comparison," Applied Economics, vol. 40, no. 21, pp. 2749-2764, 2008.

[25] R. D. Banker, A. Charnes, and W. W. Cooper, "Some models for estimating technical and scale inefficiencies in data envelopment analysis," Management Science, vol. 30, no. 9, pp. 1078-1092, 1984.

[26] R. Fare, S. Grosskopfand, and C. Pasurka, "The effect of environmental regulations on the efficiency of electric utilities: 1969 versus 1975," Applied Economics, vol. 21, no. 2, pp. 225-235, 1989

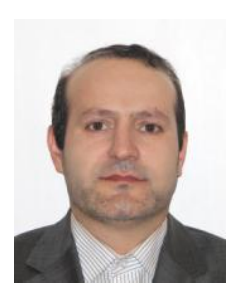

Ahmad Assadzadeh is an associate professor at the faculty of Economics and Business in the University of Tabriz, Iran. In 1991, he completed an MA degree in the field of Economics at Imam Sadegh University, Tehran. In 1998, he obtained a Ph.D. in the field of Economics from the University of Western Sydney, Australia. Since 1997, he worked as an academic member at the University of Tabriz, where he was involved in lecturing several topics in Economics and Ecommerce both at graduate and postgraduate levels. His research profile includes over 30 papers published in scientific journals and over 40 research papers presented in the national and international conferences. His area of interest covers; ecommerce and epayments, income distribution and poverty as well as health economics. Recently, his book titled "Introduction to Ecommerce" has gained much attention in the academia and was adopted as a text book for the student of economics.

Dr. Assadzadeh is a member of the Iranian Economists Association and also a member of the Iranian Ecommerce Scientific Association. Most recently, Dr Assadzadeh become a member of the International Economics Development Research Center (IEDRC). 